\title{
Covid-19 in Indonesia:
}

\section{Threat and Fear of Family Instability}

\author{
Sudirman Hasan 1," Syabbul Bachri ${ }^{2}$, Ramadhita $^{3}$, Fakhruddin $^{4}$, Erfaniah Zuhriah ${ }^{5}$ \\ 1, 2, 3, 4, 5 Universitas Islam Negeri Maulana Malik Ibrahim Malang \\ *Corresponding author. Email: sudirman@syariah.uin-malang.ac.id
}

\begin{abstract}
The Indonesian people still experience severe concerns about family stability because the COVID-19 pandemic has not stopped yet. The family burden is getting heavier every day. There has not been a comprehensive study of family instability related to COVID-19. The purpose of this study is to complement the shortcomings of previous writings by examining in detail the relationship between COVID-19 and family instability. This study is empirical research of family instability because it collects data from actors who experience family instability. The results of this study indicate that the problems caused by COVID-19 have not only resulted in the decline of the community's economy but have caused family instability in various ways, including social anxiety, unstable children's education, and an increase in the divorce rate. As shown in this paper, family instability cannot be resolved only with an approach of government power. However, it must also be overcome by a family counseling approach that touches the root of family problems. This research can be continued with a focus on studying the effects of COVID-19 on individuals using an anthropological approach.
\end{abstract}

Keywords: COVID-19, Threat, fear, Family instability

\section{INTRODUCTION}

The Indonesian people are experiencing fear and threats due to the COVID-19 pandemic. Every day, reports of positive cases and patient deaths are uploaded by the government through its official website. The highest number of the case currently occurred on 8 October 2020, reaching 4,850 infected people. As the smallest unit of society, the family feels the direct impact of COVID-19, which triggers instability. Family instability has made household situations abnormal and can create big problems. Of course, this situation is very concerning for many parties and needs to get the right solution immediately. According to Abdullah [1] this situation can cause psychological trauma in the family.

Furthermore, there is no comprehensive study on family instability related to COVID-19. However, several studies on COVID-19 and anxiety have been carried out by Pakpour et al. [2], Dsouza et al. [3], and Bendau et al. [4]. The results of their research focused on people's anxiety about avoiding COVID-19 by using masks, washing hands, and buying necessities. Even in extreme cases, this anxiety leads to suicides. This fact is due to the continuous mass media coverage. Studies on the effect of COVID-19 on education on society show that educational institutions and educators are forced to do online learning [5][6][7]. The impact of COVID-19 has affected the family's economic resilience (Wiresti, 2020), which can increase the divorce rate [8]. This paper is different from the previous study because the focus on family instability by combining three significant problems has not been present in the previous research. In the discussion section, some solutions to this problem are presented.

The purpose of this study is to complement the shortcomings of previous writings by examining in detail the relationship between COVID-19 and family instability. Researchers have not carried out studies on COVID-19 and family. Generally, studies about COVID-19 are more on medical reviews of COVID-19 settlement. The impact on the family is still not under discussion. Therefore, studies that link the COVID-19 phenomenon in Indonesia with family instability are interesting. This paper describes family instability in (1) a continuous form of social anxiety, (2) unstable children's education, and (3) increased family conflict. With this explanation, it is clear that family instability is a new challenge for the Indonesian people and needs an immediate solution. 


\section{LITERATURE REVIEW}

\subsection{Family and Social Fear}

Social fear is a psychological disorder that often occurs in society. Anxiety can be dangerous if the levels are excessive. Someone who has social anxiety always tries not to face situations that are frightening to him. If forced to face, there will be great stress [9]. Fear is a reaction to certain threatening situations resulting from developments, changes, and new experiences [10]. Fear results in feeling tense, restless, afraid, nervous, and sweating. Anxious people feel confined and far from feeling free to get a sense of freedom [11]. Fear that occurs in a person is caused by self-disability, physical constraints, conflicts, or past trauma. [12]

Social fear occurs in all aspects of life, such as education [13], [14], health [15], [16], and economy [17]. The development of information technology also encourages the creation of social anxiety. Various studies have shown that excessive use of gadgets, the internet, and social media affects social anxiety [18][20]. Social anxiety does not only occur in adults but also children. Resolving anxiety in adolescents requires the support of parents [21]. Social anxiety also happened during the COVID-19 outbreak. Pandemic, COVID-19 triggered stress, fear, and threats to society [1], [22]-[26]. The spread of COVID-19 causes a person to be unsafe in various places. The community tries to avoid public spaces to prevent outbreaks [27]. Prevention of COVID-19 transmission causes social distancing behavior [28]. Social anxiety can change people's behavior. Low pressure can lead to preventive actions such as wearing masks and washing hands, and high levels of fear can lead to socially disruptive behaviors such as panic buying [2]. In other cases, the spread of COVID-19 has resulted in suicides, fear of infection, economic problems, loneliness, quarantine, and lockdown [3]. Bendau's research shows that increased anxiety about COVID-19 is influenced by media coverage [4].

\subsection{Family and Children's Education}

Education is a conscious and planned effort to create an atmosphere of learning and the learning process to actively develop their potential to have religious, spiritual strength, self-control, personality, intelligence, noble character, and skills needed by themselves, society, nation, and state. The child is defined as someone who is not yet 18 (eighteen) years old, including children who are still in the womb. Education is held by modeling, building willingness, and developing students' creativity in the learning process [29]. Education in Indonesia is divided into three models: (1) formal education, (2) non-formal, and (3) informal. [30] The various models above are organized in an open system through face-to-face or over long distances.

The spread of COVID-19 has had an impact on education from early childhood education to higher education. Educational institutions and educators are forced to do online learning [5][6][7]. Educators' creativity in delivering material will affect increasing the competence of students amid the COVID-19 pandemic - for example, project-based online learning. [31] However, online education during a pandemic raises various problems, such as the high cost of internet access [32]. Children from socially disadvantaged families have few learning opportunities both in terms of time and learning experiences [33].

\subsection{Family and Divorce}

To overcome the spread of the COVID-19, the Indonesian government made a policy through Regulation of the Minister of Health of the Republic of Indonesia number 9 of 2020 on guidelines for largescale social restrictions (PSBB) to accelerate the handling of COVID-19. (Article 13 PMK Number 9 2020 on Guidelines for Large-Scale Social Restrictions in Handling COVID-19, 2020). The impact of government policy on limiting these activities affects the family's economic resilience [34], which will disrupt family stability. It is estimated that in 2020 the number of divorces will increase due to COVID-19. [8]

Several studies have shown that economic factors are the leading causes of divorce in several Indonesia regions. Nurmahmudah and Syaefullah, for example, stated that 5296 divorce cases in 2018 arose as a result of economic problems, which led to prolonged conflicts between married couples [35]. Studies conducted by Afzal et al. in Aceh also show that socio-economic factors are the leading cause of divorce [36]. The same thing was also expressed by Nurul Adhha when researching the factors that cause divorce in Padang. [37]. Indeed, not all divorces are caused by economic factors. The homogamy factor of a married couple's education, for example, also significantly affects the stability of the household [38]. The 2018 research data in Indramayu, West Java, also shows that there were 3296 cases of divorce filed by applicants with primary school graduate backgrounds and 2724 lawsuits filed by junior high school graduate applicants. However, it is clear that the economic downturn due to COVID-19 also impacts education in Indonesia, as it is recorded that 56 percent of private schools in Indonesia are also experiencing financial difficulties. So it is feared that the number of school dropouts will increase rapidly.[39] 


\section{METHODS}

Research on family instability is generally divided into two types: normative family instability research and empirical family instability research. This study includes an empirical study of family instability because it collects data from actors who experience family instability. The types of data used in assessing family instability are primary and secondary data. This research relies on the use of documents and interviews. There are two types of documents used, news documents and statistical documents. News documents are obtained from online newspaper portals, such as Republika and Merdeka, which provide accurate family instability information. The statistical records are taken from the information center for trusted institutions that document family problems, such as the COVID-19 website and religious courts.

\section{RESULT}

Until October 2020, the Indonesian people are still experiencing deep concerns about family stability because the COVID-19 pandemic is not over. The number of sufferers' cases continues to increase, and the average daily positive cases reach up to 4,000 . The highest daily figure occurred on October 8, 2020, reaching 4,850 cases.[40] Epidemiologists predict daily cases will exceed the figure above 5,000. This situation shows that there is no sign that the COVID-19 will disappear. Therefore, the community, especially the family, is threatened with great difficulties. COVID-19 not only causes a decline in the family economy but also creates family instability. It is indicated by three important phenomena: the continuous emergence of social fear, the poor quality of children's education, and high family conflicts that lead to divorce.

\subsection{Continuous Social Fear}

Every day, the Indonesian people are haunted by the fear of the dangers of COVID-19, which has infected 320,564 people and killed 11,580 people (as of 8 October 2020). This data is placed on the COVID19.go.id website. With the COVID-19 situation, people are hampered from working outside the home. They have to meet basic needs. Some things that make the community more stressed are the Large-Scale Social Restrictions policy, the adaptation of new habits, and the community's exclusion.

First, the government has taken many ways to respond to the unstoppable spread of COVID-19. One of them is the imposition of large-scale social restrictions. Many regions have implemented this policy, including DKI Jakarta, West Java, and East Java [41]. People are prohibited from leaving the house except to meet urgent needs. Offices, companies, and many shopping centers are closed, and traditional markets have an odd-even system. People are isolated in their homes. With this policy, people cannot work and carry out routine social activities. More than 3.5 million employees were laid off and even terminated. [42] This situation, of course, hurts the family's economic and psychological condition.

Second, the New Normal era is an adaptation of new habits that must be carried out. Everyone is required to wear a mask when leaving the house. Even in various activities indoors, for example, everyone must also wear a mask in the office. Physical distancing and the use of masks are mandatory requirements for implementing these activities [43]. The government even banned wedding receptions [44]. Then, the government relaxed by providing strict rules. The habit of washing hands with soap or hand sanitizer has become a new habit. Temperature measurement with a thermo-gun is also standard procedure [45]. These all emphasize family situations that require high awareness.

Third, community exclusion often occurs to families who receive foreign guests, especially families infected with COVID-19. A family that welcomes guests, especially from an area called the red zone, will be approached by community leaders to ask their guests to leave immediately. After that, the family may not interact with the surrounding community for 14 days. They must carry out independent isolation to prevent the virus from spreading to their neighbors. If they do become infected, the attitude of the people is even stronger. The community immediately isolates them and provides a kind of "police line" so that their neighbors are not allowed to visit or take care of them. As a result, this situation offers severe social pressure, which can be even more dangerous than the virus itself.

\subsection{Unstable Children Education}

When COVID-19 became increasingly rampant, the learning process in the class had to be stopped. Schools from kindergarten, high school, and college are finally closed. The learning process moves to a virtual facility, which becomes a challenge for some families. Good cellphones and full quotas do not guarantee that online learning will run smoothly. A weak provider signal keeps the learning process constrained. This is a family challenge that makes the pressure even harder.

Although learning is not carried out in the school building, the cost of education is not reduced. Many schools do not cut the education cost, especially private schools and Islamic boarding schools, whose existence depends on student tuition. At the university level, campuses cannot provide internet quotas and still apply the full Single Tuition Fee. It has an impact on the burden of parents getting bigger. Parents must face the fact that their income is decreasing and the school fees 
of their children are increasing. This situation threatens the stability of the family.

Distance learning makes it difficult for teachers to transfer knowledge to students and becomes a burden for parents to accompany their children to learn. The burden on parents has multiplied. Besides working hard to earn a living for school fees, they also have to become impromptu teachers at home. Several respondents described their experiences as follows.

"I actually can't teach my child. I'm tired of work. After that, I also have to help my children do much homework. I am confused. No one can relieve (R1, 45 years).

"I can't teach my children because the leaning material is too difficult, especially my son is in high school because I am only a junior high school graduate (R2, 48 years)

"If the children learn using the cellphone, usually only one hour, then the children play games and are lazy to learn (R3, 29 years).

From the expressions R1, R2, and R3, it is evident that parents are depressed because they cannot understand their child's school lessons. It is even harder if the child is at an advanced level whose tasks are more complex. Sometimes, children play games instead of studying. Many parents give up because they can't do anything about this situation.

\subsection{Divorce Case Increase}

COVID-19 makes the family situation even more fragile. In addition to the relationship between children and parents, COVID-19 also causes husband and wife relationships to experience severe challenges. When household economic conditions are safe, the family can still be stable and easy to maintain. However, if the economy declines, many conflicts arise because of the lousy economy. Husbands can no longer provide a living, while basic needs must be available every day. The wife who could not adapt to this situation finally filed for divorce. The wife hopes that by separating from her husband, she can be independent and work more freely to support herself and her children. Interview with three women who wanted to divorce at the Malang District Religious Court showed that the women filed for divorce to get away from their husbands because they did not provide a living (R4, 45 years), did not give the living expenses and children's tuition fee (R5, 36 years), and committed domestic violence (R6, 30 years).

Divorce in Indonesia is very high. Various sources indicate that COVID-19 has increased the number of divorces. For example, at the Soreang Religious Court, the average divorce application process is usually around 800 files. However, in June 2020, this court had received 1,012 divorce suits. This shows that society makes divorce the last way to solve family problems. The Minister of Religion has several times said that divorce in Indonesia is at an alarming stage, primarily due to the COVID-19 pandemic (www.republika.co.id). The causes include husband-wife disputes, a weak economy, neglect of one party, as shown by the Malang City Religious Court. First, the most common reason in religious courts is the incompatibility of partners. The incompatibility of husband and wife causes more than $50 \%$ of divorces in carrying out the household dish. The second is the economy. Economic problems remain an essential reason for divorce cases. The data shows that financial crises cause about $30 \%$ of divorce cases. Third, the neglect of one party. When a husband and wife cannot accept their partner's weaknesses, one of them leaves his partner to reduce family problems. This phenomenon is certainly more dominant today, and family resilience is at stake.

\section{DISCUSSION}

This research results in the fact that COVID-19 has threatened family stability. The family burden is getting heavier every day. The situation of instability has almost penetrated the majority of families. Family instability can be seen from the macro position that involves the family and the environment. The public feels worried and threatened by COVID-19 that has not subsided. Large-scale social restrictions and new normal adaptations are not easy for families to survive.

Moreover, work activities are also limited. Many families become poor because the head of the household can no longer earn a living. Besides, children's education is hampered due to limited learning infrastructure. Family instability peaks when a married couple cannot live together. The COVID-19 impact adds to the long list of divorce cases in Indonesia on the grounds of continuous conflict and economic weakness. From this, it can be seen clearly that COVID-19 has created family instability that can destroy households.

This study shows that family problems that are actually complex have become even worse with the presence of COVID-19. Instability cannot be avoided. The main problem causing this instability is the unpreparedness of the family to adapt to new situations immediately. This unpreparedness is triggered by limited skills and limited parental education and communication patterns between parties in the family that are constrained to get income from many sources. He can still earn other income when his primary source of income stops. Also, the limited education of parents makes it difficult for them to accompany their children to study. Poor communication patterns and the attitude of blaming a weak partner may trigger domestic problems. In turn, it may lead to divorce. Thus, family 
instability must be faced with a healthy attitude and quick adaptation to save family integrity.

This research confirms that three essential factors trigger instability. First, the government's unpreparedness in educating the public to be ready for COVID-19. Second, the community's communal habits result in high anxiety for the family. Third, the weak psychological resistance of family members.

This study has a different perspective from previous studies. Several studies on COVID-19 and anxiety have been conducted by Pakpour et al, [2] Dsouza et al.,[3] and Bendau et al. [4]. Their research results focus on people's anxiety about avoiding Covid-19 by using masks, washing their hands, and panic buying. Even in extreme cases, this anxiety leads to suicides. It is due to the continuous press reports of the mass media. Also, studies on the effect of COVID-19 on education show that educational institutions and educators are forced to do online learning [5][6][7]. The impact of COVID-19 has affected the family economy [34], which can trigger an increase in the divorce rate [8]. This paper differs from previous studies because the focus on family instability combines three significant problems that have not been found in previous studies.

This research suggests several recommendations: strengthening the socio-economic community, mentoring parenting communities, and family counseling. The government can carry out socioeconomic strengthening, community organizations, and working groups that have exceptional attention to reducing the impact of COVID-19. Assistance to parents is vital because parents have qualified skills to educate their children at home in this online era. Finally, continuous family counseling is needed to overcome family instability. Open communication patterns and understanding a partner's situation can reduce family problems and strengthen families in this severe pandemic.

\section{CONCLUSION}

COVID-19 has not only resulted in a decline in the community's economy but has caused greater family instability in various ways. As shown in this paper, family instability cannot be resolved only with an approach of government power. However, a family counseling approach must also be overcome that touches the root of family problems. This study shows that excessive anxiety, unstable children's education, and conflict with family members can trigger major family problems that lead to household breakdowns. Of course, it has a harmful effect not only on separated couples but also on children, extended family, and society. This study is limited to family instability in terms of social problems due to COVID-19. Studies on the effects of COVID-19 on individuals need to be carried out with an anthropological approach using cultural aspects as one of the analytical tools.

\section{REFERENCES}

[1] I. Abdullah, 'COVID-19: Threat and fear in Indonesia.', Psychological Trauma: Theory, Research, Practice, and Policy, vol. 12, no. 5, pp. 488-490, Jul. 2020, doi: 10.1037/tra0000878.

[2] A. H. Pakpour, M. D. Griffiths, and C.-Y. Lin, 'Assessing Psychological Response to the COVID19: The Fear of COVID-19 Scale and the COVID Stress Scales', Int J Ment Health Addiction, May 2020, doi: 10.1007/s11469-020-00334-9.

[3] D. D. Dsouza, S. Quadros, Z. J. Hyderabadwala, and M. A. Mamun, 'Aggregated COVID-19 suicide incidences in India: Fear of COVID-19 infection is the prominent causative factor', Psychiatry Research, vol. 290, p. 113145, Aug. 2020, doi: 10.1016/j.psychres.2020.113145.

[4] A. Bendau et al., 'Associations between COVID19 related media consumption and symptoms of anxiety, depression and COVID-19 related fear in the general population in Germany', European Archives of Psychiatry and Clinical Neuroscience, Jan. 2020, doi: 10.1007/s00406-020-01171-6.

[5] R. H. S. Aji, 'Dampak Covid-19 pada Pendidikan di Indonesia: Sekolah, Keterampilan, dan Proses Pembelajaran', SALAM: Jurnal Sosial dan Budaya Syar-i, vol. 7, no. 5, Art. no. 5, Apr. 2020, doi: 10.15408/sjsbs.v7i5.15314.

[6] D. Ayuni, T. Marini, M. Fauziddin, and Y. Pahrul, 'Kesiapan Guru TK Menghadapi Pembelajaran Daring Masa Pandemi Covid-19', Jurnal Obsesi : Jurnal Pendidikan Anak Usia Dini, vol. 5, no. 1, Art. no. 1, Jul. 2020, doi: 10.31004/obsesi.v5i1.579.

[7] M. Lubis, D. Yusri, and M. Gusman, 'Pembelajaran Pendidikan Agama Islam Berbasis E-Learning (Studi Inovasi Pendidik MTS. PAI Medan di Tengah Wabah Covid-19)', Fitrah: Journal of Islamic Education, vol. 1, no. 1, Art. no. 1, Jul. 2020.

[8] S. Suhandjati, 'Perceraian di Tengah Covid-19', Jun 26 , 2020. https://www.suaramerdeka.com/news/berandaulama/232572-perceraian-di-tengah-covid-19 (accessed Oct. 11, 2020).

[9] A. Asrori, 'Terapi Kognitif Perilaku Untuk Mengatasi Gangguan Kecemasan Sosial', Jurnal Ilmiah Psikologi Terapan, vol. 3, no. 1, Art. no. 1, Mar. 2016, doi: 10.22219/jipt.v3i1.2128.

[10] R. Humaida, C. Ningsih, E. Kurniawati, and U. Komarudin, 'Diagnosis dan Terapi pada Pasien Gangguan Ansietas Menyeluruh Pria usia 60 
tahun', Jurnal Medula, vol. 6, no. 1, Art. no. 1, Dec. 2016.

[11] A. Hayat, 'Kecemasan dan Metode Pengendaliannya', Khazanah: Jurnal Studi Islam dan Humaniora, vol. 12, no. 1, Art. no. 1, Sep. 2017, doi: 10.18592/khazanah.v12i1.301.

[12] D. F. Annisa and I. Ifdil, 'Konsep Kecemasan (Anxiety) pada Lanjut Usia (Lansia)', Konselor, vol. 5, no. 2, Art. no. 2, Jun. 2016, doi: $10.24036 / 02016526480-0-00$.

[13] A. L. Arumsari and J. Ariati, 'Hubungan Antara Dukungan Sosial Orangtua Dan Efikasi Diri Akademik Dengan Kecemasan Dalam Menghadapi Ujian Nasional Pada Siswa Kelas Xii Sma N 3 Magelang', Empati, vol. 7, no. 1, Art. no. 1, Jun. 2020.

[14] R. Y. K. Wardani, 'Hubungan Konsep Diri, Interaksi Sosial, Dan Kecemasan Terhadap Prestasi Belajar Matematika Siswa Kelas Viii', EKUIVALEN - Pendidikan Matematika, vol. 25, no. 2, Art. no. 2, Jan. 2017, doi: 10.37729/ekuivalen.v25i2.3345.

[15] F. S. Sari, 'Dukungan Sosial Dengan Kecemasanpasien Strokedi Rumah Sakit Stroke Nasional Bukittinggi', Jurnal Pembangunan Nagari, vol. 4, no. 1, Art. no. 1, Jun. 2019, doi: 10.30559/jpn.v4i1.147.

[16] T. Hadiansyah and A. Pragholapati, 'Kecemasan Keluarga Dalam Merawat Klien Skizofrenia', Jurnal Keperawatan 'Aisyiyah, vol. 7, no. 1, Art. no. 1, Jun. 2020, doi: 10.33867/jka.v7i1.161.

[17] F. K. Fauziyah and J. Ariati, 'Dukungan Sosial Teman Sebaya Dan Kecemasan Dalam Menghadapi Dunia Kerja Pada Mahasiswa S1 Tingkat Akhir', Empati, vol. 4, no. 4, Art. no. 4, Oct. 2015.

[18] D. B. Primadiana, H. E. Nihayati, and E. D. Wahyuni, 'Hubungan Smartphone Addiction Dengan Kecemasan Sosial Pada Remaja', Psychiatry Nursing Journal (Jurnal Keperawatan Jiwa), vol. 1, no. 1, Art. no. 1, Mar. 2019, doi: 10.20473/pnj.v1i1.14325.

[19] R. Ramaita, A. Armaita, and P. Vandelis, 'Hubungan Ketergantungan Smartphone Dengan Kecemasan (nomophobia)', Jurnal Kesehatan, vol. 10, no. 2, Art. no. 2, Aug. 2019, doi: 10.35730/jk.v10i2.399.

[20] S. F. Soliha, 'Tingkat Ketergantungan Pengguna Media Sosial Dan Kecemasan Sosial', Interaksi: Jurnal Ilmu Komunikasi, vol. 4, no. 1, Art. no. 1, Jan. 2015.

[21] C. Saragi and E. S. Indrawati, 'Hubungan Antara Dukungan Sosial Orangtua Dengan Kecemasan Menghadapi Masa Depan Pada Komunitas
Pemusik Regular Remaja Di Kota Semarang', Empati, vol. 8, no. 1, Art. no. 1, Mar. 2019.

[22] L. Y. Dhanani and B. Franz, 'Unexpected public health consequences of the COVID-19 pandemic: a national survey examining anti-Asian attitudes in the USA', Int J Public Health, vol. 65, no. 6, pp. 747-754, Jul. 2020, doi: 10.1007/s00038-02001440-0.

[23] D. Doshi, P. Karunakar, J. R. Sukhabogi, J. S. Prasanna, and S. V. Mahajan, 'Assessing Coronavirus Fear in Indian Population Using the Fear of COVID-19 Scale', Int J Ment Health Addict, pp. 1-9, May 2020, doi: 10.1007/s11469. 020-00332-x.

[24] N. T. P. Pang et al., 'Malay Version of the Fear of COVID-19 Scale: Validity and Reliability', International Journal of Mental Health and Addiction, p. 1, 2020, doi: 10.1007/s11469-02000355-4.

[25] K. Revathishree, S. Shyam Sudhakar, R. Indu, and K. Srinivasan, 'Covid-19 Demographics from a Tertiary Care Center: Does It Depreciate Qualityof-Life?', Indian J Otolaryngol Head Neck Surg, Sep. 2020, doi: 10.1007/s12070-020-02144-w.

[26] B. Satici, E. Gocet-Tekin, M. E. Deniz, and S. A. Satici, 'Adaptation of the Fear of COVID-19 Scale: Its Association with Psychological Distress and Life Satisfaction in Turkey', Int J Ment Health Addiction, May 2020, doi: 10.1007/s11469-02000294-0.

[27] A. Kurniawan, N. Yumna, and E. Tantri, 'Resistensi Ruang Publik Di Tengah Covid-19 Perspektif Islam Dan Komunikasi Multikultural', KOMUNIKE, vol. 12, no. 1, Art. no. 1, Jun. 2020, doi: 10.20414/jurkom.v12i1.2253.

[28] M. Bielecki et al., 'Social Distancing Alters the Clinical Course of COVID-19 in Young Adults: A Comparative Cohort Study', Clin Infect Dis, 2020, doi: $10.1093 / \mathrm{cid} / \mathrm{ciaa} 889$

[29] I. W. C. Sujana, 'Fungsi Dan Tujuan Pendidikan Indonesia', Adi Widya: Jurnal Pendidikan Dasar, vol. 4, no. 1, Art. no. 1, Jul. 2019, doi: 10.25078/aw.v4i1.927.

[30] A. Julianto, 'Kolaborasi Pendidikan Nonformal, Informal, dan Formal dalam Pendidikan Pemuda di Daerah Istimewa Yogyakarta', Diklus: Jurnal Pendidikan Luar Sekolah, vol. 3, no. 1, Art. no. 1, Mar. 2019, doi: 10.21831/diklus.v3i1.24644.

[31] K. Arizona, Z. Abidin, and R. Rumansyah, 'Pembelajaran Online Berbasis Proyek Salah Satu Solusi Kegiatan Belajar Mengajar Di Tengah Pandemi Covid-19', Jurnal Ilmiah Profesi Pendidikan, vol. 5, no. 1, Art. no. 1, May 2020, doi: 10.29303/jipp.v5i1.111. 
[32] R. Ro'fah, A. Hanjarwati, and J. Suprihatiningrum, 'Is Online Learning Accessible During COVID-19 Pandemic? Voices and Experiences of UIN Sunan Kalijaga Students with Disabilities', Nadwa, vol. 14, no. 1, Art. no. 1, Aug. 2020, doi: 10.21580/nw.2020.14.1.5672.

[33] X. Bonal and S. González, 'The impact of lockdown on the learning gap: family and school divisions in times of crisis', Int Rev Educ, Sep. 2020, doi: 10.1007/s11159-020-09860-z.

[34] R. D. Wiresti, 'Analisis Dampak Work From Home pada Anak Usia Dini di Masa Pandemi Covid-19', Jurnal Obsesi : Jurnal Pendidikan Anak Usia Dini, vol. 5, no. 1, p. 641, Aug. 2020, doi: 10.31004/obsesi.v5i1.563.

[35] Syaefullah and Nurmahmudah, 'Analysis of Causing Factors Divorce in Indramayu District, 2018 (case Study in the Religion Court of Indramayu District in 2018)', Mahakim: Journal of Islamic Family Law, vol. 2, no. 2, Dec. 2018, doi: 10.30762/mh.v2i2.974.

[36] A. Sabri, A. Jamal, and M. Nasir, 'Socio-Economic And Divorce in Aceh Province', MIMBAR : Jurnal Sosial dan Pembangunan, vol. 35, no. 2, pp. 383391, Dec. 2019, doi: 10.29313/mimbar.v35i2.5021.

[37] N. Adhha, 'Analysis of Causes of Divorce in the Perspective of Islamic Law: A Case Study in the Class 1 A Religious Court of Padang', $A L$ 'ADALAH, vol. 16, no. 1, Art. no. 1, Jun. 2019, doi: 10.24042/adalah.v16i1.2305.

[38] E. Mäenpää and M. Jalovaara, 'Homogamy in socio-economic background and education, and the dissolution of cohabiting unions', Demographic Research, vol. 30, pp. 1769-1792, Jun. 2014, doi: 10.4054/DemRes.2014.30.65.

[39] S. Huda, 'Pemerintah Diminta Antisipasi Ancaman Putus Sekolah Meningkat', medcom.id, May 01, 2020. https://www.medcom.id/pendidikan/newspendidikan/VNnXg72k-pemerintah-dimintaantisipasi-ancaman-putus-sekolah-meningkat (accessed Oct. 11, 2020).
[40] Komite Penanganan Covid-19 dan Pemulihan Ekonomi Nasional, 'Data Sebaran Covid-19 di Indonesia'. https://covid19.go.id/ (accessed Oct. 11, 2020).

[41] Y. Ernes, 'Pemprov DKI Jakarta Bahas Kelanjutan PSBB Siang Ini', detiknews. https://news.detik.com/berita/d-5207968/pemprovdki-jakarta-bahas-kelanjutan-psbb-siang-ini (accessed Oct. 11, 2020).

[42] A. M. Kurnia, 'Imbas Corona, Lebih dari 3,5 Juta Pekerja Kena PHK dan Dirumahkan Halaman all', KOMPAS.com. https://money.kompas.com/read/2020/08/04/16390 0726/imbas-corona-lebih-dari-3-5-juta-pekerjakena-phk-dan-dirumahkan (accessed Oct. 11, 2020).

[43] T. Irawati, 'Menuju Adaptasi Kebiasaan Baru', Direktorat Promosi Kesehatan Kementerian Kesehatan RI. https://promkes.kemkes.go.id/menuju-adaptasikebiasaan-baru (accessed Oct. 11, 2020).

[44] S. Ramadana, 'Covid Meningkat, Larangan Resepsi Pernikahan Mulai Dikaji | Kebencanaan'. https://www.gatra.com/detail/news/490055/kebenc anaan/covid-meningkat-larangan-resepsipernikahan-mulai-dikaji (accessed Oct. 11, 2020).

[45] Rachmatunnisa, 'Cara Kerja Thermo Gun, "Pistol" Deteksi Dini Pasien Corona', detikHealth. https://health.detik.com/berita-detikhealth/d4926029/cara-kerja-thermo-gun-pistol-deteksi-dinipasien-corona (accessed Oct. 11, 2020). 